\title{
Literary Obscenities
}





\section{Literary}

\section{OBSCENITIES}

U.S. CASE LAW AND NATURALISM AFTER MODERNISM

Erik M. Bachman

The Pennsylvania State University Press

University Park, Pennsylvania 
Library of Congress Cataloging-in-

Publication Data

Names: Bachman, Erik M., 1981—author.

Title: Literary obscenities : U.S. case law and naturalism after modernism / Erik M. Bachman.

Other titles: Refiguring modernism.

Description: University Park, Pennsylvania : The Pennsylvania State University Press, [2018] |

Series: Refiguring modernism | Includes bibliographical references and index.

Summary: "Examines U.S. obscenity trials in the early twentieth century and how they framed a wide-ranging debate about the printed word's power to deprave, offend, and shape behavior"-Provided by publisher.

Identifiers: LCCN 2017045208 | ISBN 9780271080055 (cloth : alk. paper)

Subjects: LCSH: Sex in literature-History-2oth century. | Pornography in LiteratureHistory-2oth century. | Obscenity (Law)-United States-History-2oth century. | Naturalism in literature-History-2oth century. | Lewis, Wyndham, 1882-1957-Criticism and Interpretation. | Caldwell, Erskine, 1903-1987-Criticism and interpretation. | Smith, Lillian (Lillian Eugenia), 1897-1966Criticism and interpretation.

Classification: LCC PN56.S5 B33 2018 | DDC $809 / .933538-\mathrm{dc} 23$

LC record available at https://lccn.loc.gov /2017045208
Copyright (c) 2018 Erik M. Bachman

All rights reserved

Printed in the United States of America

Published by The Pennsylvania

State University Press,

University Park, PA 16802-1003

The Pennsylvania State University Press is a member of the Association of University Presses.

It is the policy of The Pennsylvania State University Press to use acid-free paper. Publications on uncoated stock satisfy the minimum requirements of American National Standard for Information Sciences-Permanence of Paper for Printed Library Material, ANSI Z39.48-1992. 
To Walter and Kathryn Bachman, who merrily have yet to be called to account for their own manifest tendencies to deprave and corrupt 
